\title{
PROCESS OF CHANGING THE DESIGN MANUFACTURING OF A FOOD COMPANY: THE CONTRIBUTION OF PROJECT MANAGEMENT
}

\author{
PROCESSO DE MUDANCA DO DIAGRAMA \\ DE MÁQUINAS EM INDÚSTRIA ALIMENTÍCIA: A \\ CONTRIBUIÇÃO DA GESTÃO DE PROJETOS
}

\author{
Submission: $16 / 12 / 2018$ \\ Accept: $17 / 12 / 2019$ \\ Alessandro Ricardo Haj Hammoud ${ }^{1}$ \\ Gide José Fernandes ${ }^{2}$ \\ Ivete Rodrigues ${ }^{3}$
}

\begin{abstract}
Given the economic instability of Brazil, the company followed in this technical report realized the need to modernize its industrial park, with the major focus in maintaining the excellence in quality and innovation in the line of products. This work aims to describe the preparation and management of the project, considering the strategy of the organization and the alignment with the board of the company. Being the result of the knowledge acquired from the mistakes and achievements in the management history of the organization, the adopted model of project management was decisive for the success of the intervention. Through careful control, even for small budget and schedule deviations, and through the efficient organization of the steps, there was an opportunity to acquire knowledge about project management; low project cost variance (3.89\% of financial deviation, below the expectation when compared to previous projects); schedule anticipation (the rollout step was started 15 days before the planned period); a $20 \%$ increase of productivity and product quality gains ( $30 \%$ of reduction in the setup time for extraction). The well-succeeded experience in management and team training might be replicated to other projects in the company, besides contributing to strengthen the importance of project management in suppliers and similar companies.
\end{abstract}

Keywords: project management, machine diagram, machine change, food industry.

\footnotetext{
1 Master in Business Management at FIA Business School. MBA in Knowledge, Technology and Innovation at FIA Business School. MBA in Supply Chain Finance at Vanzolini Foundation. MBA in Retail from FIA Business School. Post graduate in Business Administration from Piracicaba School of Engineering. Graduate in Mechanical Production Engineering from Methodist University of Piracicaba. Executive of national and multinational companies for 22 years, managing supply chain areas such as Coca Cola, BRF and Ypê. São Paulo. Brazil. E-mail: alessandro.hammoud@faculdadefia.edu.br ORCID: https://orcid.org/0000-0002-6757-0361

2 Master in Business Management from FIA Business School. MBA from Bocconi University of Milan. More than 15 years of experience in commercial management in the industry, with a focus on employee training, skills development and team building. Successfully implemented and controlled strategies to achieve results by working with high-tech sales professionals. By supporting individual growth within high performance teams, have been able to increase revenues in unstable environments in both economic and technological terms. Shared practical experiences through courses and lectures at FACENS Faculty of Engineering in Sorocaba. São Paulo. Brazil. E-mail: gide.fernandes@faculdadefia.edu.br ORCID: https://orcid.org/0000-0002-8351-0043

3 Ph.D. in Business Administration at the Faculdade de Economia, Administração e Contabilidade da Universidade de São Paulo - FEA/USP. Master in Business Administration at Getúlio Vargas - SP (2006); MBA in project Management at Fundação Instituto de Administração, with complementation at Bentley College, Boston, USA; Graduate in Pedagogy, Qualification in School Administration, at the Universidade de São Paulo. Professor of graduation and postgraduation at the Faculdade FIA of Management and Business. She researches about value creation through innovation, projects, sustainability and corporate social responsibility. She is the author of several articles and books published both in Brazil and abroad. São Paulo. Brazil. E-mail: iveter@fia.com.br ORCID: https://orcid.org/0000-0003-4106-8389
} 


\section{RESUMO}

Frente à instabilidade econômica do Brasil, a empresa objeto deste relato técnico percebeu a necessidade de modernizar seu parque fabril, com o foco principal em manter a excelência na qualidade $e$ inovação da linha de produtos. Este trabalho objetiva descrever como foi a preparação e gestão do projeto, considerando a estratégia da empresa e o alinhamento com o conselho da organização. Fruto do aprendizado decorrente dos erros e acertos na história de gestão da organização, o modelo de gestão de projetos adotado foi determinante para o sucesso da intervenção. Por meio do controle atento, até mesmo para os pequenos desvios orçamentários e de cronograma, e pela organização eficiente das etapas, houve oportunidade de aquisição de conhecimento em gestão de projetos; baixo desvio de custos do projeto (3,89\% de desvio financeiro, abaixo da expectativa quando comparado com projetos anteriores); antecipação de cronograma (a etapa de rollout foi iniciada 15 dias antes do período planejado); aumento de produtividade em $20 \%$ e ganhos de qualidade no produto (30\% de redução no tempo de preparação para extração). A experiência bem-sucedida na gestão e formação de equipes poderá ser replicada para outros projetos da organização, bem como contribuir para fortalecer a importância da gestão de projetos em fornecedores e empresas congêneres.

Palavras-chave: gerenciamento de projetos, diagrama de máquinas, troca de máquinas, indústria de alimentos.

\section{INTRODUCTION}

In general, companies throughout the world go through periods of crisis alternated with periods of economic and financial stability due to the forces present in the global market. In Brazil, the instability of the economic indicators favors even more these oscillations. The Brazilian economy, since the beginning of the 1980s, has presented a stop-and-go behavior, in which growth cycles are alternated many times with abrupt economic slowdowns (Paula \& Pires, 2017). These constant phases of instability increased the competitive pressure and affected many segments of the Brazilian market. The survival of the national industry, subject to these variables, face comparatively bigger challenges than those found in the more developed nations (Bennett \& Lemoine, 2014).

Innovative products and processes might act as a protecting factor for the companies, helping them to keep competitive in unstable environments. The awareness about the need to innovate makes business more prone to face the moments of crisis and to increase the survival and competitiveness of the organizations (Grant, 2008).

To be a source of competitiveness, the management of innovation needs to incorporate methodologies and techniques capable of providing efficiency and efficacy. Many organizations have been seeking for the benefits that result from new technologies, in order to generate integrated and flexible industrial environments, more prepared to deal with the actual reality. The new fronts of industrial expansion value technology in production lines, with less use of labor, energy, and stocks; and faster adaptation to what the market demands (Bessant, 2013).

However, a national food company, due to oscillation of the market, had not updated its industrial facilities for years. A conservative strategy was adopted regarding innovation and modernization of the facility, because there was a concern that the investment made would not result in a gain in competitiveness. The company faced a commons dilemma to other industries: deal with its survival in the short term or invest in the modernization of its structure in order not to miss new opportunities that would arise in the future?

A more solid analysis of the strategy of the company resulted in the decision of implementing a modernization project in one of its industrial facilities, focusing mainly the quality 
excellence and innovation in the line of products. It was a risk decision due to the uncertainties and volatility of the environment external to the company, but the organization decided to invest even in the face of unknown circumstances. Due to the need to include information that is sensitive to the business, the identity of the company will remain confidential. Where necessary, the text will use the expression "company X".

Besides investment, there was another question to be addressed. How to properly manage this project? Company $X$ accumulated failures in previous projects that failed to meet costs and deadlines. One of the objectives of the project was to increase the production capacity boosting the production volume in up to $20 \%$. Given this ambitious goal, there would not be much margin for mismanagement.

Part of the difficulties found might be explained by the absence of an adequate structure to manage its projects. According to Rabechini Jr. et al (2011) this happens in most organizations that are still stuck in companies still stuck with traditional organizational models that restrict projects to their functional areas. Therefore, it is necessary to undertake efforts to adapt management models that incorporate routine activities and innovation.

In the light of this context, this study aims to report the project of modernization of the industrial facilities of company $X$. Specifically, this work will address the management project of changing the machine diagram of this food company. This term is used in industry to represent the set of devices (for example, pumps, vessels, tanks, mixers, ovens, silos, motors, different machines etc.) of an industrial plant, responsible for the whole production, that goes from the input of raw material to the exit of the final product.

The importance of this report resides in the fact that the solution found by the company resulted in gains in productivity, product quality, plant supply, and project management knowledge creation.

\section{THEORETICAL FRAMEWORK}

This session presents a discussion of the literature related to the intervention made in this company, briefly discussing issues related to the adequacy of the organizational structure, typology of projects, models of innovative management and, finally, the project management in the areas of scope, time, costs, quality and risks.

\subsection{Organizational structure for projects}

With the expansion of project activities in companies, new concerns were raised regarding the adequacy of the organizational structure. In an innovative environment, in which companies need to implement projects that involve many functional areas, the use of the traditional functional structure has limitations. In order to seek greater integration among project teams, companies began to search for new organizational forms (RABECHINI JR. et al, 2011).

Among the new organizational forms, the structure by projects started to be adopted so that projects would have the same priorities as those of the routine activities of the company, improving results in matters of deadlines, costs, and quality. However, being a high-cost alternative, the organizations started using the matrix structure, in order to make a better use of the integration of the different technical areas, a condition that is increasingly necessary in the face of contemporary technological complexity. The matrix structure seeks to distribute the project throughout the divisions of the company and, thus, is able to use better its technical capacity, 
which does not occur in a structure by projects. The costs are reduced due to the greater rationality in the use of human and technical resources. (RABECHINI, JR. et al, 2011).

Before starting the project, Company " $X$ " made a structural change in order to increase the chances of success. After analyzing the strengths and weaknesses of each type of organizational structure, the matrix structure was defined as the best one to manage the project of changing the plant diagram.

\subsection{Typology of projects}

The way a project is managed depends upon the understanding of its different dimensions. An approach to assess these dimensions is proposed by Shenhar et al. (2010), which adopt the NTCR (novelty, technology, complexity, and rhythm) model. By analyzing the project in these four proposed dimensions it would be possible to align management to achieve the established objectives.

Regarding the dimension "novelty", the aforementioned authors define it as how new the product is and how defined are the requirements and needs of the customer. In order to classify a project based in this dimension, the authors suggested three levels: a) derivative - new version of an existing project; b) platform - new line or family of products; c) innovation - new type of product never offered before to the customer.

The dimension "technology" is associated to the uncertainty about the knowledge and application of the technologies that are used in the project, being evaluate in four levels: a) low: mature technology, well-established, and mastered by the company; b) medium: there are existent technologies for non-critical parts of the project, but they are not mastered by the company; c) high: use new, recently developed, but already existent technologies; d) super high: the technology does not exist but needs to be developed during the process.

The complexity is associated to the project and to the tasks seen as a hierarchical structure of systems and subsystems in three dimensions: a) assembly - product exists independently from the rest; b) system - product that involves many interlinked subsystems; and c) matrix large-scale connection of several systems (SHENHAR; DVIR, 2007; SHENHAR et al., 2010)

Finally, the dimension "rhythm" refers to the availability of time to implement the project and the consequence of the delays, in four levels of urgency: a) regular: project that might be implemented with no major deadline; b) fast/competitive: when there is a deadline to secure a larger share of the market; $c$ ) critical: there is a deadline that if not met represents the failure of the project; d) blitz: response to an emergency or crisis in which the deadline is as short as possible.

\subsection{Model for Innovation Project Management - the stage-gates model}

Since the analysis of the typology of the project herein reported led to the conclusion that it would fit into the technology dimension, being a platform-type project - new line or family of products - the managing model adopted was the one known as stage-gates, of Cooper, which is discussed next.

The Cooper model (COOPER, 2001) acknowledges that there are organizational factors such as the inter-functionality in the execution of activities in each stage, the connection with the market, and the decision-making levels that affect the project management. Given this interconnection between different stakeholders, the author defends the existence of predetermined management stages, each one comprising a list of activities. Each stage has a gate, that is, a gate that serves to control the progress of the project through evaluation and checking. 
This management model is focused on keeping the project under control. When reaching a gate, the team of the project should evaluate if major deviations have occurred and devise correction strategies. Each gate has indicators that should be analyzed so that decision might be made on the basis of evidence. Possible management decisions in each gate would be continue, cancel, pause or restart the stage.

\subsection{Project management}

A project is a temporary effort undertaken to create a unique product, service or result. Projects and operations mainly differ in the fact that projects are temporary and exclusive, while operations are continuous and repetitive (PMI, 2014).

The main objective of the project management, according to the PMBok 3rd edition (Project Management Body of Knowledge (PMI, 2004)) is to ensure that the work is carried out within the deadline, with the budget allocated, and in accordance with the specifications. These three dimensions - time, resource, and scope - form the triple restriction and are fundamental for the success of the project. If one of these factors is affected, at least one of the other ones will also be affected. From the fourth edition of PMBoK (PMI, 2008) the concept of triple restriction was expanded. Other dimensions such as quality, resources, and risks have been added.

Therefore, in a context of reduced budgets, the project manager should apply a set of techniques to ensure that the projects are carried out on time, with assured quality, meeting the entire requested scope, and within the expected limit. However, most organizational projects do not meet these goals (PMBOK, 2014; MANFIO, LACERDA, 2014).

Shenhar and Dvir (2010) proposed that the success of a project is related to the organizational efficacy and, therefore, the temporal dimension also needs to be considered since, depending on the project, its benefits might only be earned years after the end of the project. Because of this, the authors argued that short, medium, and long term success metrics should be considered. Short-term metrics would be term, budget, and customer satisfaction; medium metrics would be return on investment; and long-term metrics would be gains in competitiveness, company longevity, and relationship building. The authors also suggest five major groups of indicators: project efficiency; customer impact; team impact; commercial and direct success; and preparation for the future.

The restrictions considered important for the success of the project of changing the machine diagram of the food industry under study are dealt with below.

- Management of the Scope of the Project

Managing the scope of a project means ensuring that the project includes all the work required, and only the work required, in order to complete it successfully. It is the basis for a good planning of the work that must be done - with all its activities - to obtain the product, service, or result according to certain characteristics. It is essential to map not only the work that needs to be done, but also to identify and report to the client the work that will not be done (PMI, 2014).

- Management of the Project Schedule.

The project schedule is started after the scope is detailed; however, it requires refinement to obtain reduced and admissible error margins. To detail the schedule, it is necessary to list the activities, estimate the duration, and the interdependencies in each one of them. Just as it is essential prepare the schedule, it is also necessary to maintain an effective control of it so that the scheduled activities do not delay (CARVALHO, 2007). 


\section{- Quality Management}

In industrial projects in which several stakeholders are involved and where there is a greater management complexity, it is necessary to create evaluation, verification, and control mechanisms at each stage of the project. This practice should be applied to the project as a whole, even if part of it is developed by third parties. During the execution of the project, the quality requirements are evaluated, considering the best technical and economic solutions (SILVA, MELHADO, 2014).

- Risk Management of the Project

The managing of risks in project management, along with opportunity assessment, is considered one of the most important tools for a successful implementation. The ability that stands out in good project management is the ability to classify the risks that may have the greatest impact on the execution of the project (Kurian, 2013). The exposure to risk for the organization during execution might be classified in three different aspects: risks before the market, financial risks, and risks of trust before stakeholders such as shareholders, creditors, and human resources (Kerzner, 2015). Listed as one of the most important factors for the balance of conflicting restrictions in the decision to enter a project (PMI, 2017), the risk before the market was one of the factors considered with rigor and attention in the intervention carried out.

Although the mismatch of information in the assessment is common in organizations, there might be different ways of prioritizing impact factors among functional departments (Larson \& Gray, 2017). In this case the expectation of return favored the decision to execute the project. Finally, the aspects related to trust risk, with priority to the figures of creditors and human resources, was also mitigated using communication and transparency systems (Kerzner, 2015).

The concern with an efficient risk management was also present in the care with the environmental impact variables in the project of changing the machine diagram. The justification is due to the role of the production structure in the strategy of the company. The relevance of the production process and how it might be affected by the physical arrangement of the equipment required to focus not only on maintaining competitiveness, but also on the care for the creation of a lean and sustainable manufacturing system (Coelho \& Rotta, 2014).

\section{METHOD AND PROCEDURES}

In terms of approach, this work follows the format of a technical report, considering that, according to Motta (2017), the difference between a production with academic emphasis and one with professional emphasis lies in its approach. While the former emphasizes the understanding, description, explanation, and even prediction of phenomena, the production with professional emphasis rests on problem solving. The approach of this study is fully aligned with the definition proposed by the author, since it deals with the implementation report of a project that aimed to solve the problems of competitiveness of the company.

According to Gregor and Hevner (2013), the technical reports are more specific and delimited. In terms of specificity, the objective of this study is to describe the problem and the solution achieved by the company that enabled it to remain competitive against its competitors. In terms of delimitation, it addresses a single company and a single project, where many factors are observed such as substitution strategy, choice of equipment supplier, raw material supply chain programming, preparation for shutdown, and alignment with the board of the organization.

In methodological terms, the protocol of Biancolino et al (2012) was followed, which recommends that the report is based on the professional and practical experience of the authors, plus 
the experience of other professionals. Thus, to complement the view of the authors, primary and secondary data were collected, including semi-structured interviews with the Senior Manager of Engineering and Projects, the Project Manager, and the Planning Manager of the Supply Chain.

Gregor and Hevner (2013) claimed that the technical reports, in general, bring contributions from lessons learned when implementing new processes, products, or projects applied to problem solving. Within this scope, this work intends to bring, as a contribution to teachers, researchers, and managers, the description of recognized management solutions within the scope of project management that were successfully used in the project to change the machine diagram of company " $X$ ".

Its development followed the protocol proposed by Biancolino et al (2012) and the guidelines of Motta (2017) that recommended the organization of the technical report in an introduction (brief, clear, and explicit about the objectives and problems to be discussed) followed by a theoretical framework related to the intervention in question. Next, the project is described, considering the diagnosis of the problem situation; the solution implemented; the management and monitoring of the project and, finally, the results obtained and final considerations.

\section{THE IMPLEMENTATION OF THE PROJECT OF CHANGING THE MACHINE DIAGRAM}

\subsection{Diagnosis of the Problem-Situation}

The company had been losing competitiveness because it had not made investments for years, which made the equipment obsolete. There was also a need to expand the market through a greater availability of its products. The company lost orders due to lack of stock volume.

In terms of project management, there was a history of projects with negative results, including high deviation, poor quality, and low organization, high costs for correction, and business erosion due to missed deadlines with clients. Regarding performance after completion and rollout, there were several projects that did not deliver the expected benefits.

Also, there was also loss of knowledge due to lack of governance and organization. The factors of success and the lessons learned were not recorded, preventing the replication of successes and the correction of errors in future projects.

To prevent the occurrence of these problems, a series of project management decisions were made that are described below.

\subsection{Analysis of the Typology of the Project}

The project in question was identified as a platform-type project, since it would involve replacing the entire machine diagram, comprising the transformation chain of the product. Listed in the diagram concept were included all the machines that transform the grain (initial raw material) by means of several selection, extraction, milling, and mixing processes until the generation of the product for sale.

Regarding technology, although it might not necessarily be considered of high technical complexity, there were reports of other projects that experienced failure in budget planning, documentation, and methodologies for selection, among other problems, which might reflect the low maturity of the company in the use of the project management technologies.

The project herein reported was classified as a system, since there was an actual risk of paralyzing the performance in a segment that the organization had resumed four years earlier. 
If this happened, it might result in erosion in the customer portfolio, reduction of market share, rupture with suppliers, and consequent strengthening of competitors. Another important factor was the relationship with creditors, which followed the dynamics of the company and, consequently, its competence in managing a project with planned capacity to increase up to $20 \%$ of the production volume.

The pace of the project was identified as one of the most critical aspects. The value of the investment for the execution of the project, although large, was not considered a novelty, due to the size of the company. However, in times of economic crisis, there would be no room for deviations in time, quality, and costs.

\subsection{Organization of the project}

In view of the risk assessment and the importance of the project, changes in the organizational structure of the project area became necessary, with the involvement of the board of directors. Due to the scale of the changes required, employees at all levels were also involved, which created a climate of expectation that, at the end of the project, they would start operating one of the most modern national plants at the forefront of the segment.

It was essential to organize the project efficiently and accurately. Moreover, in view of previous failures, the organization needed to create a successful planning, management, and application model for the execution of future projects. A high volume of investment for the next five years had been aligned with the board of shareholders which, if not well-managed, might severely impact the business and their investment return.

Two structural actions were required to achieve results that exceeded those indicated in the planning: a) hiring new professionals and a consulting firm specialized in project management and b) selecting suppliers that not only added good equipment, but also offered collaboration in the implementation of the project.

Given the financial and business magnitude of the project, were designed a structure to act in the project. Professionals involved were composed of directors, managers, consultants, coordinators and external personnel. Some professionals were part of the full time team of the project while others were part time members, although all had the same level of information and direction.

\subsection{Project Management Model}

The stage-gate model (Cooper, 2001) was used in the process of organization and conception of the project, which includes in its structure: ideation, validation, development, execution, and release. The stage-gate format (Figure 1) was adherent to the organization and was accepted by both the project team and by the senior management, since it was part of the new model in which the company was betting on. 
Figure 1 - Stage-gate for the project.

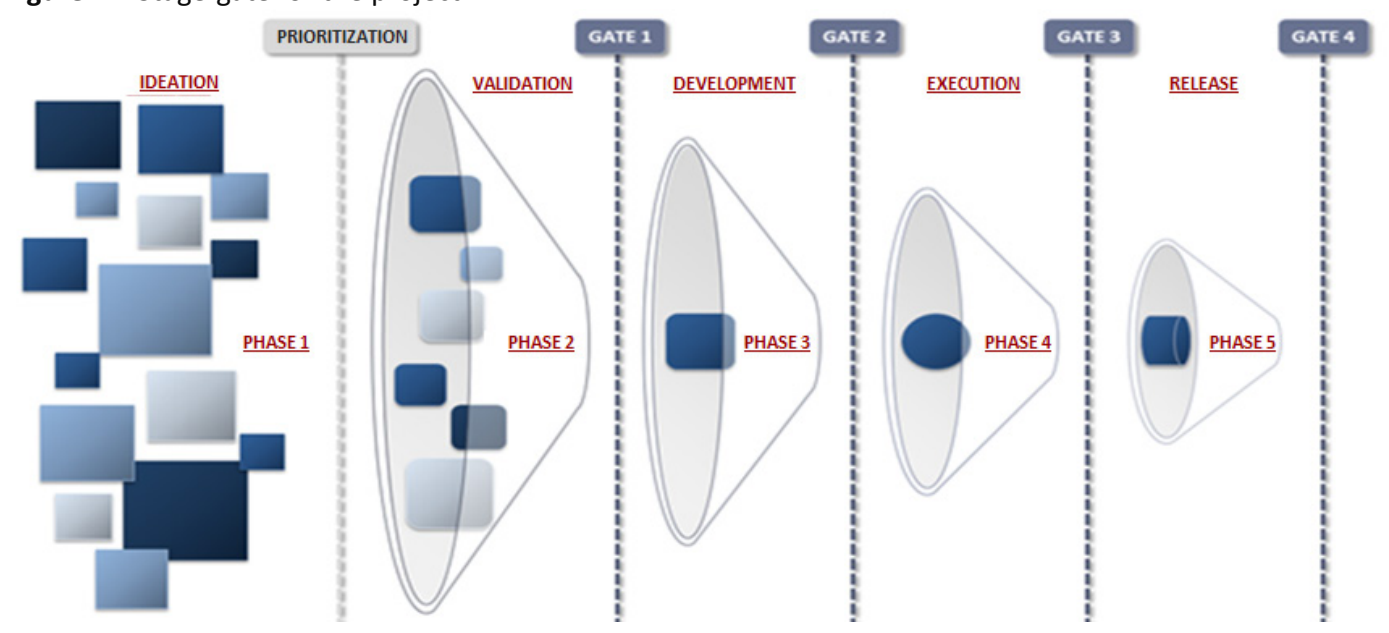

Source:(Cooper, 2011) - Adapted by the managers of "Company X".

\subsection{Project Management}

With the help of the expert consultancy, the project was managed and controlled in terms of time, cost, risk, and quality.

There was daily monitoring and the main indicators of the project were disclosed through the S curve graph (PMI, 2014) to all members of the organization by internal e-mail, murals, and conversations during shift exchanges, in all factories and offices, as shown in Chart 1.

Chart 1-S curve of the project of changing the equipment of the plant.

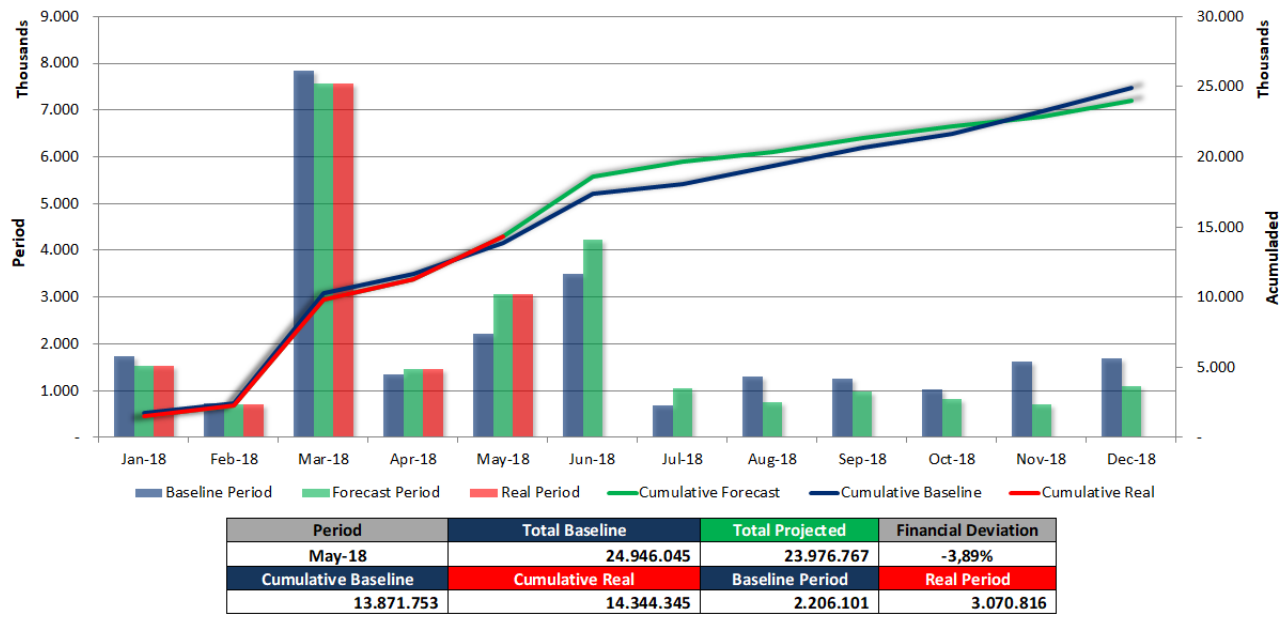

Source: (“Company X”, 2018)

The $S$ curve proved to be a very efficient way of presenting the management data for project monitoring, since it allowed a quick check of the deviations between what has been planned and what was actually done. The graphical representation of the $\mathrm{S}$ curve enabled the monitoring of the health of the project in order to help the manager to intervene in situations that could compromise the deadlines or costs.

At the end of the replacement of the plant equipment it was noted that the financial deviation was $3.89 \%$. This percentage was considered a good indicator for a complex project (Shenhar et al., 2007). Chart 1 of the S curve represents only the value of the shutdown for the 
replacement of the plant equipment. The total of the project, involving the more significant value of $\mathrm{R} \$ 180$ million and including preparation, purchase of equipment, and adjustments after implementation, is represented in the Chart 2 of the $\mathrm{S}$ curve for the whole project.

The project started in 2014 and the plant diagram was changed between April and May, 2018, which represented the critical point in the execution of the project. The $S$ curve in red (Chart 2) shows the behavior of the project until this period and the green curve was due to civil adjustments, among other factors. During the final period there was also the exchange of equipment similar to the one that was replaced before.

Chart 2 - S curve of the whole project

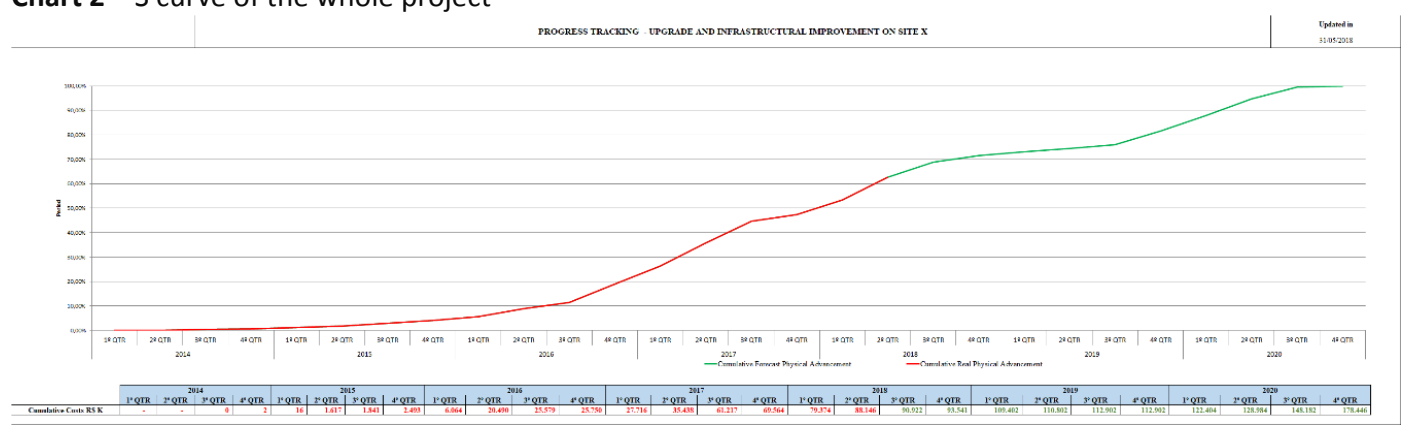

Source: (“Company X" 2018)

During the implementation of the project a dashboard was used to show the critical points, contingencies, and decisions that should have been made according to each signaling, to the board, in weekly meetings, and to the project team, in daily meetings. The dashboard considered relevant points such as financial, physical, severity, health safety, and environment.

Another relevant point in the results of this project was the low impact on the environment and the absence of accidents involving direct and indirect employees. Figure 2 shows the dashboard of the project of replacement of the plant equipment.

Figure 2 - Project monitoring dashboard to replace the plant equipment.

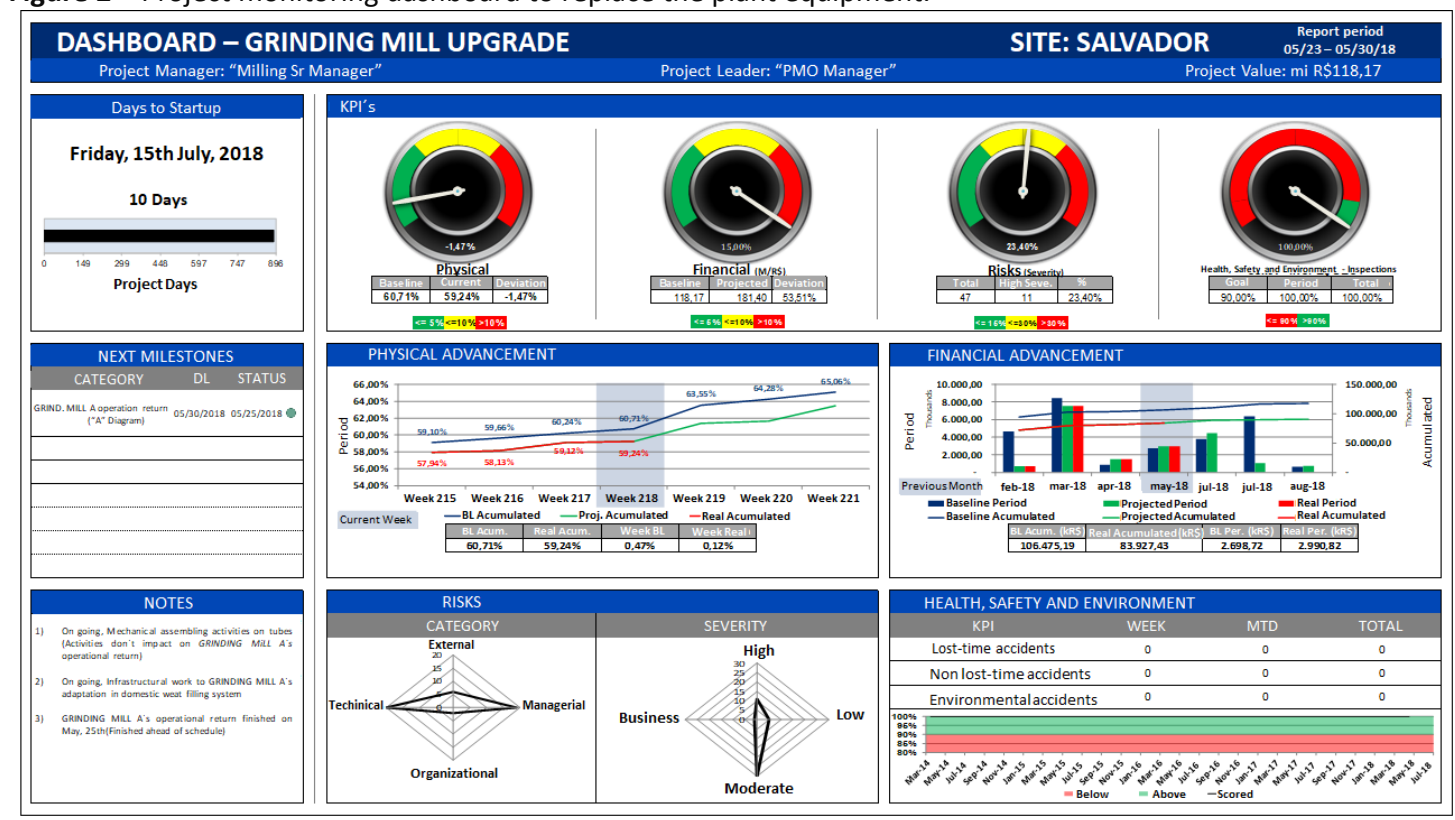

Source: (“Company X” 2018). 


\section{RESULTS OBTAINED AND FINAL CONSIDERATIONS}

The "Company X", by adopting the management methods and techniques previously presented, obtained significant gains which are described below:

- Gains of productivity: $20 \%$ due to the modernization of equipment that assembles 5 thousand more tons of products.

- Gains in the quality of the project: $30 \%$ of reduction in the setup time for extraction.

- Gains in plant supply: impact in the other units that also supply this plant.

- Gains in project deviation: $3.89 \%$ of financial deviation, below expectations when compared to previous projects.

- Gains in knowledge: the well-succeeded experience in management and formation of teams that will be replicated to other projects.

One of the possible explanations for the good results obtained might be the maturity of the team. The average time of the managing group in the company was 15 years, being qualified people for the management of projects. The formation of alliances with consulting companies was also relevant.

For the senior engineering manager "the success is the result of many factors such as supplier management, technical capacity of the team, consultancy, and communication. However, the commitment of the leaders and the PMO made everyone engage for the total success of the project".

The planning manager, in turn, said that "the major challenges were downtime and assurance of supply - for the plants and for the market - through co-makers assuring the quality of products at acceptable costs". According to the PMO "keep the project with all the expected features, communicate clearly, and manage all the expectations were my major concerns."

All the three managers agreed that delivering the project 15 before the deadline and star production without any problem was the most challenging achievement in projects of the company in the last 10 years. During the whole study with members of the "Company X" it was possible to note the awareness of overcoming the great challenge of carrying out a complex project with prominence.

By describing the entire process of conception, organization, team building, and control, adopting techniques and concepts essential to management, it was possible to record the history of actions that enabled success. These records will allow the replication of this experience for other future projects.

The formation of a multidisciplinary team, through the adoption of a matrix structure, was an important factor for the engagement in the project, the improvement in communication, and efficiency in the control.

In short, it is important to highlight to project and organization managers that planning through a cross-functional team with clear scope; selecting good suppliers, who can actively participate in the project; and engaging senior managers are factors that can make the difference between success and failure. In addition, establishing effective communication through multiple channels equalizes all the organization about the entire project status.

For this study, two limiting factors were found: a) difficulty in interviewing project members since the organization, being among the 5 largest companies that concentrate $25 \%$ of all the production of the sector, presented restrictions to disclose the model, and b) the final results for evaluating the intervention could not be surveyed, given the need to conclude some steps to end its implementation. 
Other studies might be carried out with a focus on the management of projects applied to the reality of the agricultural and food industry. Project management using fast methodologies (Sommer et al., 2015) is also an interesting area for research, with these studies likely being useful for the transmission of knowledge to companies that supply industrial equipment for this application, which are not able to create internal project teams.

\section{BIBLIOGRAPHIC REFERENCES}

Bennett, N., \& Lemoine, J. G. (2014). What VUCA Really Means for You. Harvard Business Review, 92(Jan-Fev), 1-2.

Bessant, J. (2013). Challenges in Innovation Management. In L. V. Shavinina (Ed.), The Internationall Handbook on Innovation (1st ed., Vol. 53, pp. 761-774). Quebec: Universite du Quebec. https:// doi.org/10.1017/СВ09781107415324.004

Biancolino, C. A., Kniess, C. T., Maccari, E. A., \& Jr., R. R. (2012). Protocolo Para Elaboração De Relatos De Produção Técnica. Revista de Gestão e Projetos, 3(2), 294-307. https://doi.org/10.5585/gep. v3i2.121

Carvalho, G. (2007). Passo a passo do gerenciamento de projetos. Gestão \& Tecnologia De Projetos, 2(1), 124-138. https://doi.org/10.4237/gtp.v2i1.35

Coelho, W. D. P., \& Rotta, I. S. (2014). Mudança de layout em uma fábrica de painéis elétricos. Revista de Ciencia \& Tecnologia, 17(34), 77-91.

Cooper, R. (2001). Winning at new products: accelerating the process from idea to launch. Perseus Pub.

Cooper, R. (2011). Winning at new products: Creating value Through innovation. Long Range Planning, 22, 407. https://doi.org/10.1016/0024-6301(89)90185-4

Grant, R. M. (2008). Contemporary Strategy Analysis (9th ed.). West Sussex: Wiley.

Gregor, S., \& Hevner, A. R. (2013). Positioning and presenting design science research for maximum impact. MIS Quarterly, 37(2), 337-356.

Kerzner, H. (2015). Project Management Best Practice (4th ed.). New Jersey: John Wiley \& Sons.

Kurian, G. T. (2013). The AMA Dictionary of Business and Management. New York, NY: AMACOM - American Management Association.

Larson, E. W., \& Gray, C. F. (2017). Project Managment: The Managerial Process,. Editora: Led.; McGraw-Hill/Irwin: New York, NY, USA.

Manfio, N. M.; PACHECO, D. P. (2016). Definição do escopo em projetos de desenvolvimento de produtos alimentícios: uma proposta de método. Revista Gestão \& Produção, vol.23, no.1, São Carlos, jan./mar. 2016.

Motta, G. da S. (2017). Como Escrever um Bom Artigo Tecnológico? Revista de Administração ContemporâNea, 21(5), 4-8. https://doi.org/10.1590/1982-7849rac2017170258 
Paula, L. F. de, \& Pires, M. (2017). Crise e perspectivas para a economia brasileira. Estudos Avançados, 31(89), 125-144. https://doi.org/10.1590/s0103-40142017.31890013

PMI. (2004). Project Management Body of Knowlodge - 3ạ edição. Project Management Institute (PMI), Pennsylvania.

PMI. (2008). Project Management Body of Knowlodge - 4a edição. Project Management Institute (PMI), Pennsylvania.

PMI. (2014). Project Management Body of Knowlodge - 5a edição. Project Management Institute (PMI), Pennsylvania.

PMI. (2017). The Standard for Portfolio Management. (Project Management Institute (PMI), Ed.) (4th ed.). Pennsylvania: Independent Pyblishers Group. Retrieved from http://www.pmi.org/ learning/Portfolio-Management.aspx

Rabechihni Jr. et al (2011). A organização da atividade de gerenciamento de projetos: os nexos com competências e estrutura. Gest. Prod., São Carlos, v. 18, n. 2, p. 409-424.

Shenhar, A., Milosevic, D., Dvir, D., \& Thamhain, D. (2007). Linking Project Management To Business Strategy. Pennsylvania: Project Management Institute.

Shenhar, A. J.; Dvir, D. (2010). Reinventing Project management: the Diamond approach to successful growth and innovation. Harvard Business School Press.

Silva, T., \& Melhado, S. (2014). Diretrizes para a gestão de projetos industriais. Gestão \& Tecnologia De Projetos, 9(2), 37-52. https://doi.org/10.11606/gtp.v9i2.81127

Sommer, A. F., Hedegaard, C., Dukovska-Popovska, I., \& Steger-Jensen, K. (2015). Improved Product Development Performance through Agile/Stage-Gate Hybrids: The Next-Generation Stage-Gate Process? Research-Technology Management, 58(1), 34-45. https://doi. org/10.5437/08956308X5801236.

\begin{tabular}{|c|c|c|c|}
\hline Contribution & [Author 1] & [Author 2] & [Author 3] \\
\hline $\begin{array}{c}\text { 1. Definition of research problem } \\
\text { 2. Development of hypotheses or research questions } \\
\text { (empirical studies) }\end{array}$ & $\mathrm{V}$ & $\mathrm{V}$ & $\mathrm{V}$ \\
\hline $\begin{array}{c}\text { 3. Development of theoretical propositions } \\
\text { (theoretical work) }\end{array}$ & $\mathrm{V}$ & $\mathrm{V}$ & $\mathrm{V}$ \\
\hline 4. Theoretical foundation / Literature review & $\mathrm{V}$ & $\mathrm{V}$ & $\mathrm{V}$ \\
\hline 5. Definition of methodological procedures & $\mathrm{V}$ & $\mathrm{V}$ & $\mathrm{V}$ \\
\hline 6. Data collection & $\mathrm{V}$ & & \\
\hline 7. Statistical analysis & $\mathrm{V}$ & & \\
\hline 8. Analysis and interpretation of data & $\mathrm{V}$ & & $\mathrm{V}$ \\
\hline 9. Critical revision of the manuscript & & $\mathrm{V}$ & $\mathrm{V}$ \\
\hline 10. Manuscript writing & $\mathrm{V}$ & $\mathrm{V}$ & $\mathrm{V}$ \\
\hline 11. Other (General Review) & $\mathrm{V}$ & & $\mathrm{V}$ \\
\hline
\end{tabular}

